\title{
Environmental change and the phenology of Bt cotton aphid, Aphis gossypii Glover
}

\author{
G. N. SHREEVANI ${ }^{1}$, A.G. SREENIVAS ${ }^{1}$, R.V.BELADHADI ${ }^{2}$ and B.S.JANAGOUDAR ${ }^{3}$ \\ ${ }^{1}$ Department of Agricultural Entomology, ${ }^{2}$ Department of Soil Science and Agricultural Chemistry, \\ ${ }^{3}$ Department of Crop Physiology, \\ University of Agricultural Sciences, Raichur-584 104, Karnataka, India.
}

Corresponding author's email: agsreenivas@gmail.com

\begin{abstract}
Climate change in terms of increase in atmospheric carbon dioxide and temperature has impact on agriculture including insect pests that minimize the crop yields. To address these impacts, biological studies on aphid, Aphis gossypii Glover on Bt cotton was conducted for six generations during 2013-14 and 2014-15 under different climate change conditions. The results revealed that the biometry of aphid was influenced by increased carbon dioxide $\left(550 \mathrm{ppm} \mathrm{CO}\right.$ ) and temperature (rise in $2^{\circ} \mathrm{C}$ of the prevailing temperature). This was evidenced by decrease in nymphal developmental time $(3.67 \pm 0.21$ days $)$, longevity of adult $(9.43 \pm 0.41$ days), increased fecundity $(32.46 \pm 0.95)$ and reduced life cycle $(12.28 \pm$ 0.23 days) in the elevated conditions (both $550 \mathrm{ppm} \mathrm{CO}_{2}$ with $32^{\circ} \mathrm{C}$ as well as in $550 \mathrm{ppm} \mathrm{CO}_{2}+34^{\circ} \mathrm{C}$ ). However, morphometry of aphid showed slight variations in all the treatments but, aphids under elevated conditions showed reduced body size which indicated that the fitness of aphid was effected in the enriched carbon dioxide $\left(\mathrm{CO}_{2}\right)$ and temperature conditions.
\end{abstract}

Key words: Aphis gossypii, Bt cotton, elevated $\mathrm{CO}_{2}$, elevated temperature.

In recent decade, climate change resultant global warming has become an issue of serious concern worldwide for existence of life on earth. In the near future, agriculture will inevitably face challenges caused by global climate change, which might lead to both global and local alteration. Federal agencies have reported that $\mathrm{CO}_{2}$ concentration has been increased by approximately 30 per cent since the industrial revolution which is believed to be responsible for an increase of about $0.66^{\circ} \mathrm{C}$ in mean annual global surface temperature. Meanwhile, the temperature is anticipated to increase further by 1.4 to $5.8^{\circ} \mathrm{C}$ by 2100 with equally increasing atmospheric $\mathrm{CO}_{2}$. The atmospheric $\mathrm{CO}_{2}$, which is considered to be chiefly responsible for the greenhouse effect, has increased from approximately $310 \mathrm{ppm}$ in 1950 to about $400 \mathrm{ppm}$ in the year 2011. This concentration is estimated to reach levels of 421 to $936 \mathrm{ppm}$ by the end of the $21^{\text {st }}$ century, according to forecasting models, depending on the magnitude of future human activities (Stocker, 2013).

Many studies have shown changes in foliar sugars, starch and increases in concentrations of carbon based secondary metabolites due to elevated $\mathrm{CO}_{2}$ (Stiling, 1999). The foliar nitrogen content in plants grown under increased $\mathrm{CO}_{2}$ was reported to be reduced up to 15 per cent (Heagle et al., 2002). The increase in the $\mathrm{C}: \mathrm{N}$ ratio in host plants generally decreases the nutritive quality for some feeding guilds of pests (e.g. phloem feeders, leaf miners, xylemfeeders, seed-eaters, whole-cell-feeders and leaf-chewers), leading to an increase in their food consumption rates in order to compensate for the reduced quality (Marks and Lincoln, 1996; Bezemer and Jones, 1998).

Many species of herbivorous insects tend to show altered behaviour and characteristics under enriched $\mathrm{CO}_{2}$ conditions. In case of aphids, the changes in the concentrations of some individual amino acids in the phloem affect the performance of aphids wherein, the aphids feed more to compensate necessary amounts of amino acids required for growth. The consequences differ between species and include retarded growth rates and altered development times (Coviella and Trumble, 1999; Goverde and Erhardt, 2003). Some studies concluded that the developmental time of phloem-feeding insects may be reduced by 17 per cent, and adult weight, relative growth rate (RGR) and population size may actually increase due to elevated $\mathrm{CO}_{2}$ (Bezemer and Jones, 1998; Newman et al., 2003).

\section{MATERIALAND METHODS}

Four circular Open Top Chambers (dimensions $5 \mathrm{~m}$ diameter $x 4 \mathrm{~m}$ height) constructed at MARS, University of Agricultural Sciences, Raichur were used for the present 
investigations. To maintain required conditions, pure $\mathrm{CO}_{2}$ mixed with ambient air was supplied to the chambers which were regulated by PC linked through Program Logic Control (PLC) and Supervisory Control and Data Acquisition (SCADA) system (www.neogenesisengg.com). The temperature was maintained using infrared heaters mounted two meters above the canopy. The canopy temperature of the reference plot was taken as a reference for rising the temperature in the open top chambers which were used as the elevated temperature treatments $\left(34^{\circ} \mathrm{C}\right)$. The computer with uninterrupted power supply was established for uninterrupted data recording and storing.

The carbon dioxide and temperature (abiotic factors) were considered as the treatments in the present investigations. Each open top chamber was considered as a treatment for the study along with an open plot which served as a reference plot for the study. The $\mathrm{CO}_{2}$ treatments elevated $\mathrm{CO}_{2}$ refers to $550 \mathrm{ppm}$ which were maintained with variations of $\pm 25 \mathrm{ppm}$.

The temperature mentioned in open top chambers for this study is the mean value of the canopy temperature of the reference plot recorded throughout the study period. This canopy temperature of the reference plot was taken as the ambient temperature $\left(32^{\circ} \mathrm{C}\right)$ for the treatments with only carbon dioxide as a study parameter, while, the same canopy temperature was increased to two degrees in the open top chambers which were used as the treatments where both carbon dioxide and temperature were taken as the study parameters.

\section{Biometry of aphid}

Pot culture experiment was conducted to study the biology of aphids for which $B t$ cotton plants were raised in small plastic cups of size $10 \times 7 \mathrm{~cm}$ in the OTC s' as well as in the reference plot and covered with clip cages. On 30 days old $B t$ cotton plant, one freshly emerged aphid nymph from the pure culture was introduced with fine brush. Each plastic cup served as one replication and 25 plants were maintained $(\mathrm{n}=25)$ in each OTC and reference plot (totally 125 replications) to record nymphal period, longevity, fecundity and total life cycle. The developmental changes of the aphid were observed daily wherein moulting was observed to record change in instar. The total period taken by the nymph till it started producing young ones was recorded as nymphal period. The period from start of progeny production till death of parent aphid was recorded as longevity. Longevity of wingless and alate forms was also recorded. The total number of young ones laid by the aphid was taken as fecundity per aphid. The period from the emergence of the nymph till its death was taken as the total life cycle.

The morphometry of different life stages viz., length, breadth and area of each instar; apterous and alate forms were recorded with the help of microscopic image analyser fitted with camera along with a monitor installed with software for taking measurements. Such biometric studies were repeated for three generations each year (totally six generations) so as to ascertain the effect of elevated carbon dioxide (550 ppm) and temperature on bitrophic interactions between aphid and $B t$ cotton. For generation studies, newly emerged nymphs produced on the first day of previous generation were used to conduct life table studies for next two successive generations using the same protocol as described earlier. Twenty replications for each OTC and reference plot (totally 100 replications) were maintained for this study.

\section{Statistical analysis}

Data on present investigations were analyzed using one-way analysis of variance (ANOVA). Variable treatments and replications were taken for different studies so as to suit the requirements of the experiment. Results were presented as mean \pm standard deviation for each parameter. The differences between mean values were compared with least significant difference at both $\mathrm{p}<0.01$ and 0.05 . All statistical analysis were done using SPSS version 16.0, a statistical software tool.

\section{RESULTS AND DISCUSSION}

\section{Biometry of aphid}

The influence of change climatic conditions in the form of enriched carbon dioxide and temperature on biometry of aphid was evidenced by the decrease in developmental time, longevity, increased fecundity and reduced life cycle while morphometry was slightly affected with insignificant difference across elevated and ambient treatments.

\section{Biology}

Nymphs were found to pass through four nymphal instars and resembled adult aphids except for size and colour which varied from yellowish green to greenish brown. Similar to present findings, other studies also recorded four nymphal instars of this pest on various host plants (Passlow and Roubieck, 1967; Nayar et al., 1981). Those destined to be winged adults had wing buds in the later instars. 
Table 1: Impact of elevated $\mathrm{CO}_{2}$ and temperature on biology of aphid, A. gossypii (pooled data of six generations)

\begin{tabular}{|c|c|c|c|c|c|c|c|c|}
\hline Treatments & $\begin{array}{l}\text { First } \\
\text { instar } \\
\text { (days) } \\
\end{array}$ & $\begin{array}{l}\text { Second } \\
\text { instar } \\
\text { (days) }\end{array}$ & $\begin{array}{l}\text { Third } \\
\text { instar } \\
\text { (days) } \\
\end{array}$ & $\begin{array}{l}\text { Fourth } \\
\text { instar } \\
\text { (days) }\end{array}$ & $\begin{array}{l}\text { Nymphal } \\
\text { period } \\
\text { (days) }\end{array}$ & $\begin{array}{l}\text { Longevity } \\
\text { (days) }\end{array}$ & $\begin{array}{l}\text { Fecundity/ } \\
\text { Aphid }\end{array}$ & $\begin{array}{l}\text { Life span } \\
\text { (days) }\end{array}$ \\
\hline $\begin{array}{l}550 \mathrm{ppm} \mathrm{CO}_{2} \text { with } \\
32^{\circ} \mathrm{C}\end{array}$ & $0.96 \pm 0.11^{b}$ & $0.83 \pm 0.16^{\mathrm{b}}$ & $0.99 \pm 0.18^{b}$ & $0.77 \pm 0.16^{b}$ & $3.67 \pm 0.21^{b}$ & $9.96 \pm 0.16^{\mathrm{b}}$ & $32.46 \pm 0.95^{\mathrm{a}}$ & $12.28 \pm 0.23^{b}$ \\
\hline $\begin{array}{l}550 \mathrm{ppm} \mathrm{CO}_{2}+ \\
34^{\circ} \mathrm{C}\end{array}$ & $0.93 \pm 0.14^{b}$ & $0.78 \pm 0.15^{b}$ & $0.78 \pm 0.16^{b}$ & $0.86 \pm 0.30^{\mathrm{b}}$ & $3.78 \pm 0.17^{\mathrm{b}}$ & $9.43 \pm 0.41^{\mathrm{b}}$ & $32.09 \pm 1.10^{\mathrm{a}}$ & $12.30 \pm 0.23^{b}$ \\
\hline $\begin{array}{l}390 \mathrm{ppm} \mathrm{CO}{ }_{2}+ \\
34^{\circ} \mathrm{C}\end{array}$ & $1.16 \pm 0.14^{\mathrm{a}}$ & $1.24 \pm 0.43^{\mathrm{a}}$ & $1.50 \pm 0.01^{\mathrm{a}}$ & $0.95 \pm 0.42^{\mathrm{a}}$ & $4.58 \pm 0.13^{\mathrm{a}}$ & $10.36 \pm 0.19^{a}$ & $25.93 \pm 1.03^{b}$ & $13.63 \pm 0.45^{\mathrm{a}}$ \\
\hline $\begin{array}{l}390 \mathrm{ppm} \mathrm{CO}_{2} \text { with } \\
32^{\circ} \mathrm{C} \text { (Reference } \\
\text { OTC) }\end{array}$ & $1.14 \pm 0.16^{\mathrm{a}}$ & $1.49 \pm 0.29^{\mathrm{a}}$ & $1.83 \pm 0.46^{\mathrm{a}}$ & $1.06 \pm 0.43^{\mathrm{a}}$ & $4.59 \pm 0.14^{\mathrm{a}}$ & $10.50 \pm 0.36^{\mathrm{a}}$ & $25.23 \pm 1.28^{\mathrm{b}}$ & $13.65 \pm 0.29^{\mathrm{a}}$ \\
\hline $\begin{array}{l}390 \mathrm{ppm} \mathrm{CO}_{2} \text { with } \\
32^{\circ} \mathrm{C} \text { (Reference } \\
\text { plot) }\end{array}$ & $1.23 \pm 0.20^{\mathrm{a}}$ & $1.57 \pm 0.33^{\mathrm{a}}$ & $1.84 \pm 0.12^{\mathrm{a}}$ & $1.11 \pm 0.14^{\mathrm{a}}$ & $4.67 \pm 0.16^{\mathrm{a}}$ & $10.65 \pm 0.20^{\mathrm{a}}$ & $25.06 \pm 0.76^{\mathrm{b}}$ & $13.87 \pm 0.33^{\mathrm{a}}$ \\
\hline $\mathrm{F}_{4,120}$ & $17.94 * *$ & $38.29 * *$ & $100.14 * *$ & $4.81 * *$ & $217.12^{* *}$ & $73.78 * *$ & $328.73 * *$ & $151.10 * *$ \\
\hline S.Em \pm & 0.03 & 0.05 & 0.04 & 0.06 & 0.03 & 0.06 & 0.21 & 0.06 \\
\hline $\mathrm{CD}(\mathrm{p}=0.01)$ & 0.11 & 0.21 & 0.17 & 0.23 & 0.12 & 0.21 & 0.77 & 0.23 \\
\hline
\end{tabular}

Different letters in superscript within one row indicate significantly different treatment means at $\mathrm{P}<0.05$ (LSD-test)

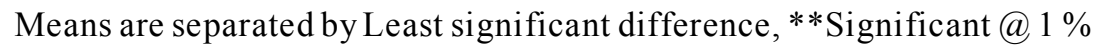

\section{Appearance}

Newly born first instar nymphs were oval in shape, dorsally convex, yellowish to greenish in colour. Antennae were six segmented, short, filiform and light black in colour. A pair of tube like structures (siphunculi/cornicles) was observed dorsally on the posterior region of abdomen. Freshly formed second instar nymphs were oval in shape and greenish in colour. They were similar to the first instar nymphs in their general appearance and morphological characters, except in body size. In freshly moulted nymph, exuvia of the preceding instar was seen near posterior end of the abdomen. Third instar nymphs were similar in their general appearance from that of previous nymphal instars. They possessed three pairs of well developed legs lateroventrally on three thoracic segments, which became more conspicuous. The antennae were well developed and black in colour. Fourth instar nymphs were similar to third instar nymphs except in body size. The morphology of the instars observed in the present study is in line with studies of Patil and Patel (2013).

\section{Duration}

The impact of various climate change treatments on various nymphal instars and morphometry of aphid is given in Table 1 and 2 respectively. The duration of first instar showed significant variation among elevated and ambient treatments wherein, the duration was less in $550 \mathrm{ppm} \mathrm{CO}_{2}+$ $34^{\circ} \mathrm{C}$ treatment and high in $390 \mathrm{ppm} \mathrm{CO}_{2}$ with $32^{\circ} \mathrm{C}$ (reference plot) $\left(\mathrm{F}_{4,120}=17.94, \mathrm{P}<0.05\right)$ (Table 1). In the similar way, the second, third and fourth instars showed decreased developmental times which were significant among elevated and ambient treatments. The average length, breadth and area of first instar nymphs varied from $0.61 \pm 0.02 \mathrm{~mm}$ to 0.64 $\pm 0.05 \mathrm{~mm}, 0.30 \pm 0.02 \mathrm{~mm}$ to $0.33 \pm 0.03 \mathrm{~mm}$ and $204.04 \pm 18.48$ $\mathrm{mm}$ to $214.80 \pm 12.07 \mathrm{~mm}$ respectively across the treatments (Table 2). However, the morphometry of nymphs did not vary significantly across elevated and ambient climate change treatments. However, smaller sized nymphs were noticed in the elevated climate change treatments as compared to the ambient treatments.

There are no reports to make comparison on the duration and morphometry of individual instars as influenced by the climate change treatments. In the present study, the durations of the instars were effected by the enriched $\mathrm{CO}_{2}$ and temperature treatments. The decreased duration and reduced size may be attributed to the increased growth rate which has led to faster completion of the stages.

\section{Total Nymphal period}

Nymphal period was significantly affected by the 
Table 2: Impact of elevated $\mathrm{CO}_{2}$ and temperature on morphometry of aphid, A. gossypii (Pooled data of six generations)

\begin{tabular}{|c|c|c|c|c|c|c|c|}
\hline Treatment & & $\begin{array}{l}\text { First } \\
\text { instar(mm) }\end{array}$ & $\begin{array}{l}\text { Second } \\
\text { instar(mm) }\end{array}$ & $\begin{array}{l}\text { Third } \\
\text { instar(mm) }\end{array}$ & $\begin{array}{l}\text { Fourth } \\
\text { instar(mm) }\end{array}$ & Wingless & Alate \\
\hline \multirow{3}{*}{$\begin{array}{l}550 \mathrm{ppm} \mathrm{CO}_{2} \text { with } \\
32^{\circ} \mathrm{C}\end{array}$} & Length & $0.62 \pm 0.04$ & $0.77 \pm 0.03$ & $0.97 \pm 0.07$ & $1.11 \pm 0.02$ & $1.13 \pm 0.03$ & $2.43 \pm 0.17$ \\
\hline & Breadth & $0.30 \pm 0.02$ & $0.37 \pm 0.01$ & $0.43 \pm 0.01$ & $0.47 \pm 0.01$ & $0.51 \pm 0.01$ & $0.48 \pm 0.02$ \\
\hline & Area & $209.06 \pm 10.77$ & $272.65 \pm 7.52$ & $378.89 \pm 13.07$ & $417.19 \pm 17.23$ & $525.54 \pm 24.37$ & $560.02 \pm 48.92$ \\
\hline \multirow{3}{*}{$\begin{array}{l}550 \mathrm{ppm} \mathrm{CO}_{2}+ \\
34^{\circ} \mathrm{C}\end{array}$} & Length & $0.61 \pm 0.02$ & $0.78 \pm 0.02$ & $0.98 \pm 0.07$ & $1.11 \pm 0.05$ & $1.12 \pm 0.05$ & $2.40 \pm 0.15$ \\
\hline & Breadth & $0.30 \pm 0.03$ & $0.38 \pm 0.02$ & $0.43 \pm 0.01$ & $0.47 \pm 0.02$ & $0.51 \pm 0.02$ & $0.48 \pm 0.01$ \\
\hline & Area & $204.04 \pm 18.48$ & $272.10 \pm 6.59$ & $379.07 \pm 15.37$ & $418.36 \pm 13.92$ & $526.08 \pm 20.75$ & $559.76 \pm 23.12$ \\
\hline \multirow{3}{*}{$\begin{array}{l}390 \mathrm{ppm} \mathrm{CO}_{2}+ \\
34^{\circ} \mathrm{C}\end{array}$} & Length & $0.62 \pm 0.02$ & $0.77 \pm 0.02$ & $0.97 \pm 0.06$ & $1.17 \pm 0.06$ & $1.19 \pm 0.07$ & $2.54 \pm 0.09$ \\
\hline & Breadth & $0.32 \pm 0.01$ & $0.40 \pm 0.02$ & $0.45 \pm 0.01$ & $0.48 \pm 0.01$ & $0.52 \pm 0.02$ & $0.49 \pm 0.01$ \\
\hline & Area & $214.80 \pm 12.07$ & $280.17 \pm 14.44$ & $387.35 \pm 8.49$ & $427.41 \pm 15.96$ & $530.11 \pm 18.15$ & $567.85 \pm 40.17$ \\
\hline \multirow{3}{*}{ 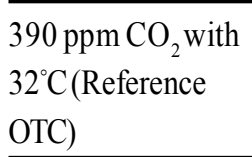 } & Length & $0.63 \pm 0.02$ & $0.79 \pm 0.03$ & $1.02 \pm 0.09$ & $1.20 \pm 0.11$ & $1.20 \pm 0.11$ & $2.52 \pm 0.12$ \\
\hline & Breadth & $0.33 \pm 0.04$ & $0.39 \pm 0.03$ & $0.45 \pm 0.01$ & $0.49 \pm 0.02$ & $0.52 \pm 0.01$ & $0.50 \pm 0.02$ \\
\hline & Area & $212.01 \pm 12.88$ & $275.07 \pm 4.23$ & $382.28 \pm 11.21$ & $427.45 \pm 16.58$ & $529.78 \pm 19.43$ & $568.97 \pm 18.29$ \\
\hline \multirow{3}{*}{$\begin{array}{l}390 \mathrm{ppm} \mathrm{CO} \text { with } \\
32^{\circ} \mathrm{C} \text { (Reference } \\
\text { plot) }\end{array}$} & Length & $0.64 \pm 0.05$ & $0.79 \pm 0.03$ & $1.01 \pm 0.06$ & $1.18 \pm 0.08$ & $1.19 \pm 0.08$ & $2.51 \pm 0.10$ \\
\hline & Breadth & $0.33 \pm 0.03$ & $0.40 \pm 0.04$ & $0.44 \pm 0.03$ & $0.47 \pm 0.02$ & $0.52 \pm 0.02$ & $0.49 \pm 0.02$ \\
\hline & Area & $212.78 \pm 9.60$ & $280.26 \pm 13.33$ & $382.11 \pm 10.81$ & $430.65 \pm 17.69$ & $533.20 \pm 26.25$ & $568.41 \pm 38.89$ \\
\hline \multirow[t]{2}{*}{ Length } & $\mathrm{F}_{4,95}$ & 2.37 & $2.84^{*}$ & 1.40 & $6.15^{* *}$ & $4.53^{* *}$ & $4.35^{* *}$ \\
\hline & $\begin{array}{l}\mathrm{CD} \\
(\mathrm{p}=0.01)\end{array}$ & NS & NS & NS & 0.06 & 0.06 & 0.11 \\
\hline \multirow[t]{2}{*}{ Breadth } & $\mathrm{F}_{4,95}$ & 4.24 & $2.94 *$ & $6.78^{* *}$ & $3.49^{*}$ & 1.71 & 1.64 \\
\hline & $\begin{array}{l}\mathrm{CD} \\
(\mathrm{p}=0.01)\end{array}$ & NS & NS & 0.02 & NS & 0.01 & NS \\
\hline \multirow[t]{2}{*}{ Area } & $\mathrm{F}_{4,95}$ & 2.01 & $3.11^{*}$ & 1.61 & $2.73^{*}$ & 0.41 & 0.34 \\
\hline & $\begin{array}{l}\mathrm{CD} \\
(\mathrm{p}=0.01)\end{array}$ & NS & NS & NS & NS & 18.29 & NS \\
\hline
\end{tabular}

Means are separated by Least significant difference, ${ }^{* *}$ Significant @ $1 \%$, NS-Non-significant

increased $\mathrm{CO}_{2}$ levels where it decreased significantly compared to ambient levels $\left(\mathrm{F}_{4,120}=217.12, \mathrm{P}<0.05\right)$. The $550 \mathrm{ppm} \mathrm{CO}_{2}$ with $32^{\circ} \mathrm{C}$ treatment recorded minimum period of $3.67 \pm 0.21$ days and was on par with the $550 \mathrm{ppm} \mathrm{CO}_{2}$ $+34{ }^{\circ} \mathrm{C}$ treatment $(3.78 \pm 0.17$ days $)$. Whereas, the ambient treatments recorded more duration, wherein, $390 \mathrm{ppm} \mathrm{CO}_{2}$ with $32^{\circ} \mathrm{C}$ (reference plot) recorded highest $(4.67 \pm 0.16$ days) nymphal period (Table 1). Our findings are consistent with studies of Alexander et al., (2012) and Chen et al., (2004).

\section{Adult longevity}

Adults were oval in shape and bottle green to dark green in colour. They were larger in body size than the nymphs and possessed a pair of well developed conspicuous black coloured cornicles at posterior region of abdomen.
The black coloured antennae were much larger in size than the nymphal stages. Wings when present were in two pairs and transparent with black veins and were held roof like over the abdomen at repose. Winged adults were long, soft bodied and yellow to dark green with a black head and thorax. Wingless adults were long, uniform in color and yellow to dark green. The antennae and cornicles were shorter than those of winged adults (Patil and Patel, 2013).

Average adult longevity varied from $9.43 \pm 0.41$ days to $10.63 \pm 0.20$ days across different climate change treatments. The elevated treatments showed significant difference with all the ambient treatments $\left(\mathrm{F}_{4}, 120=73.78\right.$, $\mathrm{P}<0.05)$. The $550 \mathrm{ppm} \mathrm{CO}_{2}+34{ }^{\circ} \mathrm{C}$ treatment recorded minimum longevity $(9.43 \pm 0.41$ days $)$ whereas, the ambient treatments particularly $390 \mathrm{ppm} \mathrm{CO}$ with $32^{\circ} \mathrm{C}$ treatment (reference plot) recorded maximum longevity $(10.65 \pm 0.20$ 


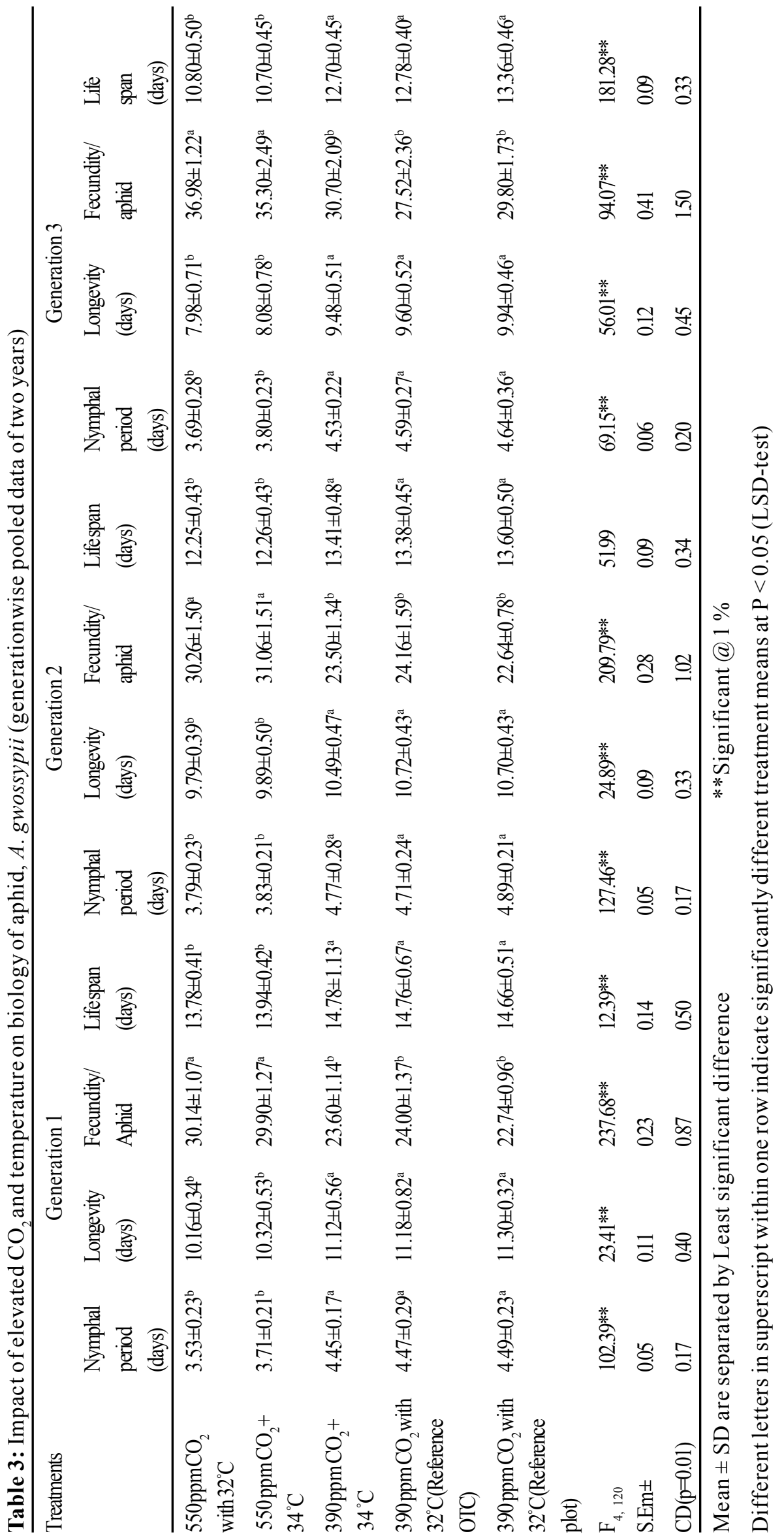


days) (Table 1). The length and breadth of the wingless adult ranged from $1.12 \pm 0.05 \mathrm{~mm}$ to $1.20 \pm 0.11 \mathrm{~mm}$ and $0.51 \pm$ $0.01 \mathrm{~mm}$ to $0.52 \pm 0.01 \mathrm{~mm}$ across the treatments while the area of the wingless adults ranged from $525.54 \pm 24.37 \mathrm{~mm}$ to $533.20 \pm 26.25 \mathrm{~mm}$ respectively. The wingless adults showed significant variation in morphometry in elevated and ambient treatments wherein, the elevated treatments recorded less morphometric measurements. The length and breadth of the alate ranged from $2.40 \pm 0.15 \mathrm{~mm}$ to $2.54 \pm$ $0.09 \mathrm{~mm}$ and $0.48 \pm 0.01 \mathrm{~mm}$ to $0.50 \pm 0.02 \mathrm{~mm}$ across the treatments while the area of the alate ranged from 559.76 $\pm 23.12 \mathrm{~mm}$ to $568.97 \pm 18.29 \mathrm{~mm}$ respectively (Table 2 ). In the present study, the decreased longevity in the elevated climate change treatments may be reasoned to the increased their growth rate and decreased developmental times and hence smaller in size. Similar findings were reported by Alexander et al., (2012).

\section{Fecundity}

Reproductive potential of $A$. gossypii was studied by counting the number of individuals produced by each gravid aphid during its reproduction period. The fecundity in elevated conditions varied significantly with the ambient treatments $\left(\mathrm{F}_{4,120}=328.73, \mathrm{P}<0.05\right)$. Pooled data of six generations revealed that the elevated treatments recorded more progeny production, wherein $550 \mathrm{ppm} \mathrm{CO}_{2}$ with $32^{\circ} \mathrm{C}$ treatment recorded maximum $(32.46 \pm 0.95)$ which was on par with $550 \mathrm{ppm} \mathrm{CO}+34{ }^{\circ} \mathrm{C}$ treatment $(32.09 \pm 1.10)$. Whereas, $390 \mathrm{ppm} \mathrm{CO}_{2}$ with $32^{\circ} \mathrm{C}$ (reference plot) recorded least fecundity $(25.06 \pm 0.76)$ which was on par with rest of the ambient treatments (Table 1). Our findings are in line with studies of Chen et al., (2005), Chen et al., (2004) and Oehme et al., (2011).

\section{Total lifespan}

The total lifespan in the elevated climate change treatments was decreased significantly as compared to ambient levels $\left(\mathrm{F}_{4,120}=151.1, \mathrm{P}<0.05\right)$. Pooled data of six generations revealed that the elevated treatments recorded the least lifespan wherein, $550 \mathrm{ppm} \mathrm{CO}_{2}$ with $32^{\circ} \mathrm{C}$ recorded $12.28 \pm 0.23$ days. Whereas, $390 \mathrm{ppm} \mathrm{CO}_{2}$ with $32^{\circ} \mathrm{C}$ (Reference OTC) recorded maximum lifespan (13.87 \pm 0.33 days) (Table 1). These results indicate that the aphid has completed its development at a faster rate in the elevated conditions. Our results are in line with other studies who reported that aphids reared on spring wheat at enriched carbon dioxide conditions had a shorter lifespan, whereas, the opposite effect was found for aphids reared on rapeseed while average number of nymphs of the two pest species showed both an increase under enriched carbon dioxide conditions (Oehme et al., 2011).This shows that the response is species-specific for some crops.

In the present study, generation-wise pooled data of two years on biology of aphid revealed that the nymphal period, longevity and lifespan has significantly decreased while the fecundity increased in elevated treatments as compared to ambient treatments. In the pooled data of $F_{1}$ generations of two years, the nymphal period ranged from $3.53 \pm 0.23$ to $4.49 \pm 0.23$ days $\left(\mathrm{F}_{4,120}=102.39 \mathrm{P}<0.05\right)$; the longevity ranged from $10.16 \pm 0.34$ to $11.30 \pm 0.32$ days $\left(\mathrm{F}_{4}\right.$, $\left.{ }_{120}=23.41, \mathrm{P}<0.05\right)$; the fecundity ranged from $22.74 \pm 0.96$ to $30.14 \pm 1.07$ days $\left(\mathrm{F}_{4,120}=237.68, \mathrm{P}<0.05\right)$ and lifespan ranged from $13.78 \pm 0.41$ to $14.78 \pm 1.13$ days $\left(\mathrm{F}_{4,120}=12.39, \mathrm{P}<0.05\right)$ respectively across the treatments. Likewise, the pooled data of subsequent $\mathrm{F}_{2}$ and $\mathrm{F}_{3}$ generations remained same with respect to increase and decrease in the biological parameters across the treatments. However, the nymphal period increased in the $\mathrm{F}_{2}$ generation in all the treatments but later it decreased in the $\mathrm{F}_{3}$ generation while, the other parameters viz., longevity and lifespan gradually decreased across the generations whereas, the fecundity increased from first generation to third generation (Table 3).

The present findings clearly depicted that, biology of aphid was greatly affected by enriched carbon dioxide and temperature treatments. Some similar studies on aphid biology showed that responses of aphid populations to elevated carbon dioxide were species-specific (Hughes and Bazzaz, 2001). The reasons for this difference include the possibility that aphids may be able to compensate for changes in host plant quality by altering the feeding behaviour or by synthesizing amino acids.

\section{CONCLUSION}

Overall, in the present study, the increase in atmospheric carbon dioxide and temperature has resulted in reduction in developmental rate and increased fecundity leading to more generations and thus more crop damage per year. Moreover, the present study was conducted for six generations (multiple generations) which has given reliable evidence for host-specific response as well as response of this particular insect (Aphis gossypii) to climate change which is further useful to design management strategies to this pest for future climate changed situations.

\section{ACKNOWLEDGEMENTS}

First author duly acknowledge the financial aid 
provided by the University Grants Commission, New Delhi, India in the form of Rajiv Gandhi National Fellowship for my Ph.D. Research work. Authors thank Dr. Vijaya Wali (Statistician) for the help with data analysis of my research work and Mr. Praveen Patwari and Mr. Prashant, Neogenesis Engineering ltd., for their support in technical aspects of Open Top chambers.

\section{REFERENCES}

Alexander, M. A., Marcy, G. F., Tiago, T. R and Italo, S. C. P. (2012). Effect of climate change on longevity and reproduction of Sipha flava (Hemiptera: Aphididae). Flo. Entomol., 95(2): 433-444.

Bezemer, T. M. and Jones, T. (1998). Plant-insect herbivore interactions in elevated atmospheric $\mathrm{CO}_{2}$ : quantitative analyses and guild effects. Oikos., 82: 212-222.

Chen, F. J., Gang, W. and Fajar, G. (2004). Impacts of elevated $\mathrm{CO}_{2}$ on the population abundance and reproductive activity of aphid, Sitobion avenae Fabricius feeding on spring wheat. J. Appl. Entomol., 128: 723-730.

Chen, F. J., Fajar, G. and Parajulee, M. N. (2005). Impact of elevated $\mathrm{CO}_{2}$ on tri-trophic interactions of Gossypium hirsutum, Aphis gossypii and Leis axyridis. Env. Ent., 34: $37-46$.

Coviella, C.E. and Trumble, J.T. (1999). Effects of elevated atmospheric carbon dioxide on insect-plant interactions. Conserv. Biol., 13: 700-712.

Goverde, M. and Erhardt, A. (2003). Effects of elevated $\mathrm{CO}_{2}$ on development and larval food-preference in the butterfly, Coenonympha pamphius (Lepidoptera, Satyridae). Glob. Change Biol., 9:74-83.

Heagle, A.S., Burns, J.C., Fisher, D.S. and Miller, J.E. (2002). Effects of carbon dioxide enrichment on leaf chemistry and reproduction by two spotted spider mites (Acari: Tetranychidae) on white clover. Env. Ent., 31:594-601.

Hughes, L. and Bazzaz,A. B. (2001). Effects of elevated $\mathrm{CO}_{2}$ on five plant-aphid interactions, Entomol. Exp. Appl., 99: 87-96.

Marks, S. and Lincoln, D.E. (1996). Anti-herbivore defense mutualism underelevated carbon dioxide levels: a fungal endophyte and grass. Env. Ent., 25: 618-623.

Nayar, K. K., Ananthakrishanan, T.N. and David, B. K. (1981). General and Applied Entomology. Tata McGraw Hill Publ. Co. Ltd., New Delhi, p. 203.

Newman, J.A., Gibson, D.J., Parsons, A.J. and Thornley, J.H. M. (2003). How predictable are aphid population responses to elevated $\mathrm{CO}_{2}$ J. Anim. Ecol., 72: 556-566.

Oehme, V., Hogy, P., Franzaring, J.,Zebitz, C.P.W. and Fangmeier, A. (2011). Response of spring crops and associated aphids to elevated atmospheric $\mathrm{CO}_{2}$ concentrations. $J$. Appl. Bot. Food Qual., 84:151 - 157.

Passlow, T. and Roubieck, M.S. (1967). Life history of cucurbits aphid (A. gossypii). Qd. J. Agril. Sci., 24: 101-102.

Patil, S. J. and Patel, B. R. (2013). Biology of Aphid, Aphis gossypii Glover (Hemiptera: Aphididae) infesting Isabgol crop. J. Med. Plants Res., 3(6):44-51.

Stiling, P., Rossi, A.M., Hungate, B., Dijksta, P., Hinkle, C.R., Knott, W.M. and Drake, B. (1999). Decreased leaf-miner abundance in elevated $\mathrm{CO}_{2}$ : reduced leaf quality and increased parasitoid attack. Ecol. Appl., 9: 240-244.

Stocker, T. F., Qin, D., Plattner, G. K., Tignor, M., Allen, S. K., Boschung, J., Nauels, A., Xia, Y., Bex, V. and Midgley, P. M. (2013). Climate Change: The physical science Basis. Contribution of working group I to the $5^{\text {th }}$ assessment report of the IPCC, Cambridge University press, Cambridge, U.K and New York, NY, USA.,p.1535. 